\title{
Denver Developmental Screening Test in two-year old infants delivered by vacuum extraction
}

\author{
Meriah Sembiring, Iskandar, Amir Syarifuddin, Bistok Saing \\ Department of Child Health, Medical School, University of North Sumatra/ H Adam Malik Hospital, Medan
}

\begin{abstract}
The aim of this study was to determine the developmental retardation of infants of two years of age who were delivered by vacuum extraction. This cross-sectional study examined 44 infants delivered by vacuum extraction, comprising 25 males and 19 females who were born in Tembakau Deli and St. Elizabeth Hospitals, between August 1993 until February 1994. The examination included interview and physical examination in the patient's house. Chi-square statistics analysis was used with a significant level of $95 \%(p=0.05)$. The results showed that of the 44 infants delivered by vacuum extraction, 28 $(32 \%)$ had had were found with mild asphyxia, while 2 infants $(5 \%)$, whose mothers work as private clerk and entrepreneur. had development retardation. We concluded that there was no significant difference in development between infants delivered by vacuum extraction and those who were born spontaneously. Developmental retardation was found in infants whose mothers lack time to communicate. [Paedlatr Indones 2001;41:27-32]
\end{abstract}

Keywords: Denver Developmental Screening Test, vacuum extraction, mental retardation

NewBorns have A COMPLETE NeRVe STRUCture. The growth and association between nerve cells increase particularly in the first two years of life. Consequently, physical, cognitive, and neurological developments occur particularly in this period. Therefore, the first two years of life is often considered as a gold chance where stimulation and intervention may produce best result. ${ }^{1,2}$ However, some factors related to brain injuries can delay the maturation process. One of the factors is intracranial bleeding in prenatal period. . $^{3.5}$

Several studies indicate that the use of vacuum extraction tends to increase from year to year. Broekhuizen found that the frequency had increased from $0.6 \%$ in 1979 to $3.1 \%$ in $1984 .{ }^{6}$ In Pimgadi Hospital, Medan, Hady reported that the frequency was

Correspondence: Meriah Sembiring, MD. Department of Child Health, Medical School, University of North Sumatera/HAdam Malik Hospital, JI. Bunga Lau No. 17, Medan, Indonesia. Presented at the 10 th Congress of The Indonesian Pediatricians Society, Bukit Tinggi, 22-25. 1996 .
$0.7 \%$ in 1970 and $8.9 \%$ in $1982 .{ }^{7}$ In Sardjito Hospital, Yogyakarta, Widhanartho et al found $8.7 \%$ of labors were assisted by vacuum extraction. ${ }^{8}$ Vacuum extraction increases mechanical trauma to infant's head which may cause intracranial bleeding, leading to symptoms of brain damage such as convulsion, cerebral palsy, and mental retardation. ${ }^{3.4 .8-11}$ Plauce found that $0.35 \%$ of intracranial blceding occurred in infants delivered by vacuum extraction. ${ }^{4}$ Bredstruk et al reported that cerebral irritation occurred in $2.9 \%$ of infants delivered by vacuum extraction. ${ }^{12}$ There are controversics among experts about the effects of delivery using vacuum extraction to the infants' development. Hanigan ${ }^{3}$ and Blennow et $\mathrm{al}^{13}{ }^{13}$ reported neurological or developmental disorders in children who had been assisted by vacuum extraction at birth, while Dahlin, ${ }^{14}$ Hariyono, ${ }^{15}$ and Marbun et ${ }^{1},{ }^{16}$ found no difference in the psychomotoric activity of infants delivered by vacuum extraction and those born spon. taneously. We conducted this study to sce the effects 
of vacuum extraction to two years old infants' devel. opment by using Denver Devclopmental Screening Test (DDST), ${ }^{16.18}$ and to analyze potential factors relating to the infants' development, i.e., Apgar-scores, educational degree, profession of mother, economic status, number of children, and gender.

\section{Methods}

This study was conducted from August 1, 1995 until February 29, 1996, using cross-sectional design, in all infants delivered at term by vacuum extraction. Vacuum extraction was indicated for those mothers who werc planned for spontaneous labor but had failed to do s-after one hour of complete opening, and head location was at Hodge III. The study was conducted in Tembakau Deli and Elisabcth Hospitals Mcdan. The control group was taken from spontancous and full-term born infants in the same hospitals.

Subjects were exactly two years of age when thcy were studicd; age of less 15 days was rounded downward, while age of equal or more than 15 days was rounded upward. ${ }^{16.17}$ All data pertaining to labor history were obtaincd from medical records. Subjects were selected by simple random sampling which was taken from the list of infants delivered by vacuum extraction in those hospitals. The estimated sample size using formula ${ }^{19}$ gave 44 subjects. Infants born with congenital anomaly, low birth weight (LBW), meningitis or encephalitis, head trauma, convulsion without fever were excluded from the study. Those who had changed the address werc also excluded.

The developmental status of the infants was determined by a general pediatrician (one of the authors) using DDST I including sector 4, i.e. personalsocial, fine motor adaptation, language, and gross motoric activity. The results were interpreted based on the following criteria: ${ }^{16.17}$

1. Abnomal, if found two sectors with two or more delays, or one sector with two or more delays and one sector with a delay, in this sector age line does not exceed an item.

2. Delayed, if they failed on an item, in which all of them were located on the left side of the age line.

3. Questionable, if found two or more delays in a sector, or one more delay in a sector and in the same sector the age line docs not exceed an item.

4. Normal, if the test result was not questionable nor abnormal.
Determination of social economic status was based on the World Bank criteria, i.e, $:^{20}$ (1) Competent, if the income was 75.000 rupiahs/month/ capita; (2) Incompetent, if the income was less than 75.000 rupiahs/month/capita.

Asphyxia was determined based on Apgar Score, ${ }^{21}$ i.e., (1) Normal: Apgar scores of 7-10; (2) Mild or moderate asphyxia: Apgar scores of 4-6; (3) Severe asphyxia: Apgar scores of 0-3.

The parent's education degrec was determined hased on formal education, i.e., elementary school, junior high school, senior high school, and academy or university level. The parent's profession was determined hased on the amount of salary gained, either daily or monthly. The number of children in a family was hased on the number of live horn children whose parents take responsibility for their needs. Staristical analysis used was chi-squared test with Yate correction and significance level is $5 \%(p=0.05)$.

\section{Results}

The number of infants born during the seven month period was 911,60 infants of them were delivered fullterm by vacuum extraction. Sixteen infants was excluded from this study; two because they died, ten infants with severc asphyxia, and four infants lived out of Medan District. The 44 infants became the study subjects; as the control group 44 infants born spontancously werc selected.

In Table 1 can been seen the characteristics of the infants, including sex, Apgar scores, discases ever suffered, economic status, and parent's cducation and profession. The number of male subjects outnumbered femalc ( $58 \%$ vs. $42 \%$ ). Threc yuarters of the infants had never suffered from illncss, whereas $25 \%$ had suffered illnesses (diarrhea, upper respiritory tract infection) that needed no hospitalization. None of the infants suffered convulsion without fever, meningitis, encephalitis, nor head injury, so the affect to the study could he as ignored.

In this study 42 of the infants delivered by vacuum extraction (95\%) developed nornally and two infants (5\%) developed abnormally. The developmental disturbance occurred in the language and gross motor sector (Table 2). The majority of infants delivered by vacuum extraction suffered from mild asphyxia $(32 \%)$ and out of them two infants (2\%) had developmental disturbance (Table 3). Sixty-three parents 
TABLE 1. CHARACTERTSTIC OF CHILD

\begin{tabular}{|c|c|c|c|c|c|c|}
\hline \multicolumn{3}{|c|}{ Characteristic } & \multirow{2}{*}{$\begin{array}{l}\text { Study } \\
25\end{array}$} & \multirow{2}{*}{$\begin{array}{l}\text { Control } \\
26\end{array}$} & \multirow{2}{*}{$\begin{array}{l}\text { Total } \\
51\end{array}$} & \multirow{2}{*}{$\begin{array}{l}\% \\
58\end{array}$} \\
\hline 1. & Sex : & Male & & & & \\
\hline & & Fernale & 19 & 18 & 37 & 42 \\
\hline \multicolumn{7}{|c|}{ 2. Apgar score } \\
\hline & & Mild-moderate asphyxia & 28 & 0 & 28 & 32 \\
\hline & & Normai & 16 & 44 & 60 & 68 \\
\hline \multirow[t]{6}{*}{3.} & Disea & se ever be suffered & & & & \\
\hline & No & & 30 & 36 & 66 & 75 \\
\hline & Yes & & 0 & 0 & 0 & . \\
\hline & & Meningitis & 0 & 0 & 0 & - \\
\hline & & Convulsion without fever & 0 & 0 & 0 & - \\
\hline & & Others (diarrhea, URI) & 14 & 8 & 22 & 25 \\
\hline \multirow[t]{3}{*}{4.} & Econc & omic status & & & & \\
\hline & & Competence & 36 & 29 & 65 & 74 \\
\hline & & Less competence & 8 & 15 & 23 & 26 \\
\hline \multirow[t]{5}{*}{5.} & Educa & ation of father & & & & \\
\hline & & Primary school & 0 & 0 & 0 & - \\
\hline & & Junior high school & 0 & 0 & 0 & - \\
\hline & & Senior high school & 13 & 17 & 30 & 34 \\
\hline & & Universily & 31 & 27 & 58 & 66 \\
\hline \multirow[t]{5}{*}{6.} & Educ: & ation of mother & & & & \\
\hline & & Primary school & 0 & 0 & 0 & - \\
\hline & & Junior high school & 4 & 2 & 6 & 7 \\
\hline & & Senior high school & 26 & 31 & 57 & 65 \\
\hline & & University & 14 & 11 & 25 & 28 \\
\hline \multirow[t]{7}{*}{7.} & Occur & pation of father & & & & \\
\hline & & Civil employee & 10 & 5 & 15 & 17 \\
\hline & & Army & 1 & 0 & 1 & 1 \\
\hline & & Private clerk & 19 & 28 & 47 & 53 \\
\hline & & Entrepreneur & 9 & 8 & 17 & 19 \\
\hline & & Farmer & 0 & 0 & 0 & - \\
\hline & & Others & 5 & 3 & 8 & 9 \\
\hline \multirow[t]{7}{*}{8.} & Occu & pation of mother & & & & \\
\hline & & Civil employee & 8 & 6 & 14 & 16 \\
\hline & & Army & 0 & 0 & 0 & . \\
\hline & & Private clerk & 11 & 10 & 21 & 24 \\
\hline & & Entrepreneur & 1 & 2 & 3 & 3 \\
\hline & & Farmer & 0 & 0 & 0 & - \\
\hline & & Others & 5 & 3 & 8 & 57 \\
\hline
\end{tabular}

(72\%) were economically competent whereas 23 parents $(28 \%)$ were less competent. Two infants with economically competent parents indicated delayed de. velopment (Table 4). Table 5 indicated three stratification of mothers' education, i.e. 57 mothers $(65 \%)$ from the senior high school group, 25 mothers (29\%) from the higher education, and 6 mothers $(7 \%)$ from the junior high school group. There was one infant suffering

cation was senior high school and higher education.

Table 6 shows that 50 mothers $(57 \%)$ were housewives, 20 mothers $(23 \%)$ were private clerks, 14 mothers (16\%) were civil government employee, and two mothers were entrepreneurs (2\%). There was $I$ in- fant suffered from abnormal development whose mother was entrepreneur and emp̧loyee.

Thirty nine families (44\%) had two to three children, 35 families $(41 \%)$ had one child, and 12 families $(14 \%)$ had more than three children. An infant with abnormal development was a member of a family that had two to three chiluren (Table 7). Table 8 de. picts 50 infants $(58 \%)$ were male and 36 female, 1 male and I female infants had delayed development.

\section{Discussion}

We found that 42 infants $(95 \%)$ had normal development and two infants $(5 \%)$ had developmental 
TABLE 2. MEAN BLOOD CHOLESTEROL IN RELATION TO BODY FORM

\begin{tabular}{llll}
\hline & & Status of development & \\
\cline { 2 - 4 } Type of Delivery & Normal & Abnormal & Total \\
\hline Vacum of extraction & 42 & 2 & 44 \\
Spontaneus & 44 & 0 & 44 \\
\hline Total & $\mathbf{8 6}$ & $\mathbf{2}$ & $\mathbf{8 8}$ \\
\hline $\mathrm{X}^{2}=2.047 \mathrm{df}=1$ & $\mathrm{P}>0.05$ & &
\end{tabular}

TABLE 3. STATUS OF DEVELOPMENT BY APGAR SCORE

\begin{tabular}{llll}
\hline Apgar Score & \multicolumn{2}{c}{ Status of development } & Total \\
\cline { 2 - 3 } & Normal & Abnormal & \\
\hline Vacum of extraction & 26 & 2 & 28 \\
Spontaneus & 60 & 0 & 60 \\
\hline Total & 86 & 2 & 88 \\
\hline X & & & 8 \\
\hline
\end{tabular}

$X^{2}=3,385 \quad d l=1 \quad p>0.05$

TABLE 4. STATUS OF DEVELOPMENT BY ECONOMIC STATUS

\begin{tabular}{llll}
\hline Economic status & \multicolumn{2}{c}{ Status of development } & Total \\
\cline { 2 - 4 } & Normal & Abnormal & \\
\hline Competence & 63 & 2 & 65 \\
Spontaneus & 23 & 0 & 23 \\
\hline Total & 86 & 2 & 88 \\
\hline$X^{2}=0,724 \mathrm{df}=1$ & $\mathrm{p}>0.05$ & &
\end{tabular}

TABLE 5. STATUS OF DEVELOPMENT BY ECONOMIC STATUS

\begin{tabular}{llll}
\hline Eduction of Mother & \multicolumn{2}{c}{ Status of development } & Total \\
\cline { 2 - 3 } & Normal & Abnormal & \\
\hline Junior high school & 6 & 0 & 6 \\
Senior high school & 56 & 1 & 57 \\
Academic/University & 24 & 1 & 25 \\
\hline Total & $\mathbf{B}$ & 2 & 88 \\
\hline $\mathrm{X}^{2}=0,68 \mathrm{df}=1 \quad \mathrm{p}>0.05$ & &
\end{tabular}

abnormalities. The development disturbances were in the language and gross motor sectors. Statistically there was no significant correlation between types of labor and infants' developmental status $(p>0.05)$. Dahlin indicated in the study that there was no difference in psychomotoric activities between infant delivered by vacuum extraction and spontaneously born infants. ${ }^{14}$

Hariyono indicated of 234 infants and six of the infants delivered by vacuum extraction had normal development. ${ }^{15}$ Marbun found ten infants delivered by vacuum extraction who had normaldevelopment. ${ }^{16}$
Augustine in his study on infants delivered by vacuum extraction found no permanent brain destruction. ${ }^{22}$ The results of this study confirmed the previous reports.

Table 3 indicated 28 infants with mild-moderate asphyxia, 26 of whom were in normal development and 2 infants had abnormal development. Statistically there was no significant correlation between mildmoderate asphyxia and infants' development. $(p>0.05)$. This was in accord with Lenstrup's ${ }^{23}$ work who found that from 32 infants who were bom with severe asphyxia none had mental disturbance. 
TABLE 6. STATUS DEVELOPMENT BY PROFESSION OF MOTHER

\begin{tabular}{llll}
\hline Profession of Mother & \multicolumn{2}{c}{ Status of development } & Total \\
\cline { 2 - 4 } & Normal & Abnormal & \\
\hline Civil Government & 14 & 0 & 14 \\
Private clerk & 20 & 1 & 21 \\
Intrepreneur & 2 & 1 & 3 \\
House wife & 50 & 0 & 50 \\
\hline Total & $\mathbf{8 6}$ & $\mathbf{2}$ & $\mathbf{8 8}$ \\
\hline $\mathrm{X}^{2}=15.105$ of $=3$ & $\mathrm{p}>0.05$ & &
\end{tabular}

TABLE 7. STATUS DEVELOPMENT BY TOTAL NUMBER OF CHILDREN

\begin{tabular}{lllc}
\hline Total chlld & \multicolumn{2}{c}{ Status development } & Total \\
\cline { 2 - 4 } & Normal & Abnormal & \\
\hline 1 & 35 & 0 & 35 \\
$2-3$ & 39 & 1 & 40 \\
More than 3 & 12 & 1 & 13 \\
\hline Total & $\mathbf{8 6}$ & 2 & $\mathbf{8 8}$ \\
\hline
\end{tabular}

$X^{2}=2.542$ of $=4 \quad p>0.05$

TABLE 8. STATUS DEVELOPMENT BY SEX

\begin{tabular}{llll}
\hline \multirow{2}{*}{ Sex } & \multicolumn{2}{c}{ Status of development } & \multirow{2}{*}{ Total } \\
\cline { 2 - 4 } & Normal & Abnormal & \\
\hline Male & 50 & 1 & 51 \\
Female & 36 & 1 & 37 \\
\hline Total & 86 & 2 & 88 \\
\hline $\mathrm{X}^{2}=15.105 \quad$ of $=3$ & $\mathrm{p}>0.05$ & &
\end{tabular}

The low economic status is a factor causing delayed development. ${ }^{24}$ We observed $26 \%$ of infants with low economic status parents and $72 \%$ were economically competent. There were two infants $(2 \%)$ having abnormal development with less competent parents. Statistically there was no relation between family's economic status and children's development ( $>$ > 0.05); see Table 4. This probably means that the parents' economic status had no apparent impact for two years old infants. In this study two infants (2\%) whose mothers were entrepreneur and private clerk had development disturbance $(p<0.05)$, as indicated in Table 6.

Hall stated that delayed development of infants could be caused by the lack of care given by their parents. ${ }^{25}$ Sunarwati reported that in earlier age (six to eight months) it was important to encourage the mental stimulation to make sure that the infant would develop optimally. ${ }^{2}$ Inadequate mental stimulation in this period may give adverse impacts to the children's development, such as disturbances in psychomotoric system. Sunoko expressed that working mother who had no time to make emotional contact with their children would affect the children's development. ${ }^{26}$ The results of this study were relevant to the experts' opinions mentioned above, that is working mothers with less time to communicate with their children can cause inadequate mental stimulation of the children.

We conclude that there is no significant development difference between infants delivered by vacuum extraction and those by spontaneous labor. The development disturbance are found in infants whose mothers lack of time to communicate. 


\section{References}

1. Lazuardi S. Deteksidinidisfungsi minimalotak pada balita. J Rehab Remedikasi 1987; 1:24-30.

2. Sunarwati TS. Periode kritis pada tumbuh kembang balita. In: Deteksi dan intervensi dini penyimpangan tumbuh kembang anak dalam upaya optimalisasi kualitas sumber daya manusia, naskah lengkap Pendidikan Kedokteran Berkelanjutan Ilmu Kesehatan Anak XXXVII, Jakarta, 21. 23 November, 1996.

3. Hanigan WC, Morgan AM. Tentorial hemorrhage associated with vacuumextraction. Pediatrics 1990; 85:534-9.

4. Plauche WE. Vacuum extraction. In: Surgical obstetrics. Philadelphia: WBSaunders Company; 1992. p. 281-95.

5. Adyana IMO. Cerebral palsy ditinjau dari aspek neurologi. Cermin Dunia Kedokteran 1995; 104:37-40.

6. Brockhuizen $\mathbf{F}$, et al. Vacuum extraction vs. forceps delivery indication and complication. In: William MC, editor. Vacuum assisted delivery. Clin Perinatol 1995; 22:933-49.

7. Hady S. Morbiditas dan mortalitas neonatal dini pada ekstraksi vakum di RS Dr. Pimgadi Medan, Pertemuan Ilmiah Tahunan III Perkumpulan Obstetrik dan Ginekologi Indonesia, Medan 1984.

8. Widhanarto B, Santoso E, Sarjono A. Traumalahir di RSUP Dr. Sardjito. Kumpulan Naskah Lengkap Kongres Nasional Perinasia II, Surabaya 27-29Maret, 1986.

9. William MC. Vacuum assisted delivery. Clin Perinatol 1995;22:933-49.

10. Govaert P, Vanharsebrouck P, Praeter CD. Traumatic neonatal intracranial bleeding and stroke. Arch Dis Childh 1992; 67:840-5.

11. Menkes JH. Perinatal asphyxia and trauma. In: Textbook of child neurology. 5thed. Baltimore: Williams \& Wilkins; 1995. p. 325-7, 337.

12. Branstruch, Graham D. Prolonged labour in primigravida patient with special reference to use of caudal block and the vacuum extraction, In: HardiS, editor. Morbiditas dan mortalitas neonatal dini pada ekstraksi vakum di RS Dr. Pirngadi Medan, Pertemuan Ilmiah Tahunan III Perkum. pulan Obstetri dan Ginekologi Indonesia, Medan 1984.

13. Blennow G, Sveningsen N, Gestafson B, et al. Neonatal and prospective follow up study of infant delivered by vacuum extraction. Acta Obstet Gynecol Scand 1977; 56:189-94.
14. Dahlin K, Bjere I. The long-temı development of children delivered by vacuum extraction. Perremuan Ilmiah Tahunan III. Perkumpulan Obstetridan Ginekologi Indonesia, Medan 1984.

15. Hariyono R, Kartono DE, et al. Denver developmental screening test on children in the well-babyclinic Dr. Kariadi Hospital. Paediatr Indones 1987; 27:85-92.

16. Marbun MD, Lubis IZ, Manoeroeng SM, et al. Denver developmental screening test (DDST) pada anak di poli anak sehat RS Dr. Pimgadi Medan. Maj Kedok Nusantara 1987; 23:401-7.

17. Frankcnburg WK, Dodds JB, Fandal AW. Denver developmental screening test. University of Colorado MedicalCenter, 1977.

18. Reyes AL. Developmental disorder. A practical approach. J Pediatr Obstet Gynaecol 1990; 63:15-9.

19. Madiyono B, Moeslichan S, Sastroasmoro S, et al. Perkiraan besar sampel. In: Sastroasmoro S, Ismael S, editors. Dasar-dasar metodologi penelitian klinis. Jakarta: BinarupaAksara, 1995. p.187-212.

20. Moesis JP, Sofyan AA, Nasution D. Profil kemiskinan di Indonesia. In: Anwar MA, Bari FA, editors. Sumberdaya teknologi dan pembangunan. Jakarta: Gramedia Pustaka Unma, 1995. p. 145-94.

21. Aminullah A. Asfiksia bayi baru lahir. In: Markum AH, et al, editors. Bukuajar ilmu kesehatananak jilid I. Jakarta: Fakultas Kedokteran Universitas Indonesia, 1991. p. 261-5.

22. Augustine AE. Faeto matemal outcome following vacuum extraction. Recent experience with 625 consecutive cases. Asian Oceania J Obstet Gynaecol 1989; 10: 287-94.

23. Lenstrup J. Cerebraldamage after neonatal asphyxia. In: Illingworth RS. A Paediatrician asks why is itcalled birth injury? Br J Obstet Gynaecol 1985: 122-30.

24. Fairweather DV, Illsley R. Obstetric and social origin of mentallyhandicapped children. In: Illingworth RS, editor. A Paediatrician asks why is it called bitth injury? $\mathrm{Br}$ J Obstet Gynaecol 1985: 122-30.

25. Hal DMD. Assessment of the slow pre school. Arch Dis Childh 1989; 64:295-300.

26. Sunoko, Waspono D, Poerwadi T. Prestasi hasil belajar anak yang lahir secara ekstraksi vakum, Bagian Ilmu Kebidanan dan Penyakit Kandungan, Fakultas Kedokteran Universitas Airlangga,Surabaya 1991. 